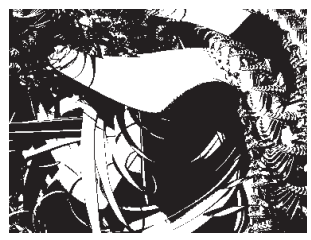

\title{
MEASUREMENT OF PERCEIVED QUALITY, PERCEIVED VALUE, IMAGE, AND SATISFACTION INTERRELATIONS OF HOTEL SERVICES: COMPARISON OF TOURISTS FROM SLOVENIA AND ITALY
}

Borut MILFELNER, Boris SNOJ, Aleksandra PISNIK KORDA Faculty of Economics and Business, Maribor

UDK: $640.41(497.4: 450)$ $338.48(497.4: 450)$

Izvorni znanstveni rad

Primljeno: 22. 10. 2009.

In the present paper, first the conceptual model of perceived value concept as a mediating variable in tourist perceptions of hotel services is presented and afterwards tested with structural equation modelling. The study reveals that: (a) the relationship between perceived hotel quality and perceived value is strong and positive; (b) the relationship between hotel quality and guest satisfaction is not direct, but rather indirect through the perceived value; (c) hotel image is significantly positively related to perceived value and perceived hotel quality; and (d) perceived value strongly impacts hotel guest satisfaction. Further, invariance analysis shows that no significant differences exist in relationships among perceived quality, image, perceived value and satisfaction between tourists from Slovenia and tourists from Italy.

Keywords: perceived value, perceived quality, image, hotel guest satisfaction, invariance

Borut Milfelner, University of Maribor, Faculty of Economics and Business, Razlagova 14, 2000 Maribor, Slovenia.

E-mail: borut.milfelner@uni-mb.si 
According to economic theory and practical experience, the importance of the perceived value of products and services grows during periods of economic recession. In such circumstances, customers are more sensitive to "value-for-money" deals. It is well known that it is unreasonable for marketers to increase the perceived value of their offerings by lowering prices, while increasing the benefits of offerings for customers can be more effective. From this perspective, the quality and image of offerings are among the most important objects in which marketers can invest. Clearly, the tourism industry is not excluded from global recession trends, since tourism as a household activity falls into the category of a luxury cost. In this sense, the research on perceived value deserves particular attention.

According to the theoretical and research tradition in marketing literature, perceived value is defined as a trade-off between benefits and sacrifices perceived by customers in a supplier's offering (Ulaga and Chacour, 2001; Woodall, 2003). Image and perceived quality are the predecessors of perceived value and satisfaction is one of its consequences. In the field of marketing, perceived quality is understood as one of the determinators of benefits. As such, it is different from perceived value. The literature reveals that perceived value research is undertaken mostly on goods, while less so on services, particularly on services related to tourism. Further, most research projects are implemented in developed countries, especially in the USA, while much less research is done in Europe and, according to our knowledge, none in transitional countries. Especially with regard to hotel services, the research mostly neglects perceived value as a critical component of overall hotel guests' perceived service, although single measurement constructs (e.g., quality, satisfaction) are developed (Bolton and Drew, 1991; Woodruff and Gardial, 1996; Cronin et al., 2000; Ekinci and Riley, 2001).

In extant tourism research on corporate or hotel image, the issue is rarely discussed and just a few empirical analyses of the relationship between image and customer satisfaction or loyalty are implemented (e.g., Kandampully and Hu, 2007; Kandampully and Suhartanto, 2000). Also, no research in extant tourism research yet deals with the direct relationship between image and perceived value.

In academic research as well as in many firms, consumer satisfaction is a salient topic (e.g., Oliver, 1997; Busacca and Padula, 2005; Homburg et al., 2006). However, review of the literature shows that the number of research projects that deal with the satisfaction of customers with physical products far outweighs the number of projects that deal with customer 
DRUŠ. ISTRAŽ. ZAGREB GOD. 20 (2011), BR. 3 (113)

STR. 605-624

MILFELNER, B., SNOJ, B. PISNIK KORDA, A.: satisfaction with services. Despite the fact that there have been numerous efforts to study tourist satisfaction (e.g., Truong and Foster, 2006; Briggs et al., 2007), there is no extant research concerning tourist satisfaction comparison between tourists who originate from different environments and cultures.

According to the above proposed research problem and the fact that, in Slovenia as well as in some other transitional countries of the European Union there has been: very few representative researches dealing with the concept of the perceived value of products; even less research that deals with this issue in the tourism industry and; no research dealing with the antecedents and consequences of perceived value, our intention is to contribute to a better understanding of the relationship among these concepts. As such, the most important goal of our study is to examine the role of perceived value as a mediating variable between perceived hotel services quality and guest satisfaction on a sample of hotel guests in Slovenia and Italy.

Also, despite the growing importance of comparative research concerning different cultural environments, there is no evidence of comparative research on perceived service value in different countries. Steenkamp and Baumgartner (1998) stressed that measurement invariance is of paramount importance in cross-national research when comparing answers and constructs from surveys. Measurement invariance refers to "whether or not, under different conditions of observing and studying phenomena, measurement operations yield measures of the same attribute" (Steenkamp and Baumgartner, 1998 , 78). With regard to tourism, only one comparative research that includes measurement of invariance is introduced (Boo et al., 2009), which considers brand equity of destination. Therefore, the second goal of our study is to test for differences in relationships between the perceptions of hotel service quality, image, value and satisfaction when comparing tourists from Italy and Slovenia.

Accordingly, we propose and test a conceptual model in which the influence of perceived hotel quality and hotel image on perceived hotel value and hotel guest satisfaction is analyzed on a sample of 410 Slovenian and Italian hotel guests. The measurement instrument was developed in Slovenia for the sake of testing cross-country differences in the relationships among researched constructs and for the exploration of invariance between tourists from Slovenia and Italy.

\section{THE DEVELOPMENT OF CONCEPTUAL MODEL}

The developing and understanding of perceived quality, perceived value, and satisfaction, and how these concepts relate to each other has occupied marketing researchers in recent years. However, the results of these efforts are diverse. Some 
DRUŠ. ISTRAŽ. ZAGREB GOD. 20 (2011), BR. $3(113)$

STR. 605-624

MILFELNER, B., SNOJ, B. PISNIK KORDA, A.: MEASUREMENT OF.. authors equate the concepts of perceived quality with perceived value and use the terms interchangeably (Caruana et al., 2000). However, equalization of these concepts is inappropriate, because perceived value has been proven to be a multidimensional concept (Gallarza and Saura, 2006; Sanchez et al., 2006; Cronin et al., 2000) that represents a trade-off between benefits and sacrifices, as perceived by customers (Zeithaml, 1988; Woodruff and Gardial, 1996; Ulaga and Chacour 2001; Woodall, 2003). Also, the review of the literature from the tourism field implies that multiple dimensions of perceived value, e.g., functional, emotional and overall value (e.g., Sanchez et al., 2006; Gallarza and Saura, 2006; Petrick 2002, 2004), may explain tourist satisfaction better than a singular concept of perceived value (Lee and Chen, 2006). On the other hand, perceived quality is defined as the consumer's judgment about an entity's (service's) overall excellence or superiority (Zeithaml, 1987). In the context of tourism, service quality is viewed mostly as the quality of the opportunities available at a destination and considered to be related to a tourist's experience quality (Crompton and Love, 1995). Therefore, if quality is one of the major benefits sought by customers, it cannot be equal to value.

Taking into account the relationship between quality and satisfaction, some authors neglect the role of value and propose only a direct relationship between quality and satisfaction. However, models that consider only a direct relationship between quality and satisfaction provide an incomplete picture of the drivers of customer satisfaction, because the role of sacrifices, which is typically incorporated in perceived value, is neglected (McDougall and Levesque, 2000). Concerning the quality-value-satisfaction chain, results of different studies to date (Gallarza and Saura, 2006; Sanchez et al., 2006; Sanchez-Fernandez and Iniesta-Bonillo, 2007), but according to our knowledge, not in the hotel industry, indicate that quality is an antecedent of perceived value, with satisfaction as behavioral consequence of perceived value. Numerous authors (Cronin et al., 2000; Petrick, 2002, 2004) closely examine the relationship between perceived quality and perceived value. The results of their researches show that higher perceived quality typically leads to higher perceived value (e.g., Sweeney et al., 1999; Teas and Agarwal, 2000), and the relationship between both concepts is positive. Furthermore, results from tourism industry studies show that quality is a direct antecedent, as well as the best predictor, of perceived value (Petrick, 2004). This finding is congruent with past research, which shows that quality, not price, is the leading determinant of perceived value for services (Bolton and Drew, 1991). Therefore, we propose: 
DRUŠ. ISTRAŽ. ZAGREB GOD. 20 (2011), BR. 3 (113)

STR. 605-624

MILFELNER, B., SNOJ, B., PISNIK KORDA, A.: MEASUREMENT OF.
H1: Higher hotel quality implies greater perceived value by hotel guests.

H2: Higher hotel quality implies greater satisfaction by hotel guests.

As can be observed from both the hypotheses, we link perceived quality directly, as well as indirectly, to hotel guest satisfaction. In the second case, the perceived value variable is considered a mediating variable between perceived quality and hotel guest satisfaction as it is often the case in other industries (e.g., Caruana et al., 2000; Cronin et al., 2000).

Customers are not able to judge service quality before the service is performed. In such cases, image can influence norm development as well as the customer expectations (Oliver, 1997). Image is described as the "overall impression" left on the minds of customers, a "gestalt", and an "idiosyncratic cognitive configuration" (Mazursky and Jacoby, 1986). Most definitions and theories behind corporate image typically describe it as an overall impression made in the minds of the public about an organization (e.g., Fombrun and Rindova, 2001; Nguyen, 2006). Therefore, image can be one of the most reliable indicators of a service organization's ability to satisfy customer desires (Nguyen and Leblanc, 2001) as well as an important influential indicator of perceived service quality (Petrick, 2004). Grönroos (2007) suggests that corporate image serves as a filtering mechanism that impacts customer perceptions. Therefore, among other guest perceptions, it should also influence his/her perception of value and indirectly, his/ her satisfaction with the hotel experience. While rare empirical research in tourism shows that the relationships among image and customer satisfaction and loyalty (e.g., Kandampully and $\mathrm{Hu}, 2007$; Kandampully and Suhartanto, 2000) are positive, none of the research yet deals with a direct relationship between image and perceived value. Therefore, we propose two hypotheses:

H3: More-favorable hotel image implies greater perceived value by hotel guests.

H4: More-favorable hotel image implies greater perceived service quality by hotel guests.

As mentioned, perceived value is one of the most important elements for gaining competitive edge and is considered to be a significant predictor of customer satisfaction and loyalty (McDougall and Levesque, 2000; Cronin et al., 2000). Many authors in different theoretical (e.g., Woodruff, 1997) and 
DRUŠ. ISTRAŽ. ZAGREB BR. $3(113)$

STR. 605-624

MILFELNER, B., SNOJ, B. PISNIK KORDA, A.: MEASUREMENT OF.. GOD. 20 (2011),

empirical studies (Patterson and Spreng, 1997; Cronin et al., 2000) conceptualize a model of perceived value as the link among quality, sacrifices and satisfaction. The results of these studies indicate that value has a strong and significant effect on satisfaction (Ulaga, 2001; Cronin et al., 2000). Gallarza and Saura (2006) explore the relationship between perceived value, satisfaction and loyalty in tourism. The results of their study indicate that perceived value is significantly related to tourist satisfaction.

Thus, we can conclude that satisfaction is a consequence of perceived value. This is also in accordance with the disconfirmatory paradigm (Oliver, 1997), which defines satisfaction as the difference between expected and perceived value. However, the results of different authors' researches (e.g., Sanchez-Fernandez and Iniesta-Bonillo, 2007) reveal a need for continuing research of value in relation to other behavioral variables, such as satisfaction, commitment and loyalty. A hypothesis is therefore set as follows:

H5: Higher perceived value implies greater hotel guest satisfaction.

Concerning the differences between tourists from Slovenia and those from Italy, tourists from Italy may have higher expectations in terms of levels of hotel services than tourists from Slovenia. Namely, tourists from Italy arrive from a well-developed country, which has for a long time been among the top performing countries in the tourism industry. On the other hand, tourists from Slovenia may have relatively lower expectations for levels of hotel services, due to their experiences of living in a former Socialist country with lower standards, fewer supplies, and lower purchasing power, etc.

Therefore, the differences in relationships among researched constructs are tested as proposed in the final hypothesis:

H6: Relationships among perceived quality, image, perceived value and satisfaction differ for tourists from Slovenia and tourists from Italy.

\section{METHODOLOGY}

The measurement instrument for the empirical study was developed in three phases. First, some of the relevant items for the questionnaire were taken from the literature. For the measurement of hotel quality, items from Petrick (2002) and adopted items from the SERV-PERF scale (Cronin and Taylor, 1992) were used. Items for measurement of perceived value were adopted from Cronin et al. (2000) and Gallarza and Saura (2006). For measurement of customer satisfaction, items 
DRUŠ. ISTRAŽ. ZAGREB GOD. 20 (2011), BR. 3 (113),

STR. 605-624

MILFELNER, B., SNOJ, B., PISNIK KORDA, A.: from Oliver's (1993) scale were used. Additionally, to representatively capture the hotel image component, we used items adopted from Herbig and Milewicz (1995) and Nguyen and Leblanc (2001).

Second, in-depth interviews with 40 tourists of different genders, ages, education levels, and from different countries were conducted in order to generate an additional pool of information. In terms of assuring content validity and to avoid redundancy, the questionnaire was examined by four specialists; three in the field of tourism and one in the field of marketing and research methods. In order to test for internal consistency of the scales used in the final study and to further reduce the number of items, a pilot survey was conducted on a sample of 410 respondents in three Slovenian tourist destinations (Ljubljana, Portorož, and Zreče). In the final study, the items for hotel quality, perceived value, perceived price and hotel image were measured on a five-point Likert scale (one $=$ "strongly disagree" to five = "strongly agree"). Twelve items were used for measurement of hotel quality, the scale for perceived value consists of six items, while the scale for hotel image of five items. Satisfaction was also measured on a five-point scale, ranging from "very dissatisfied" to "very satisfied." Data for the main research was collected from 247 Slovenian and 163 Italian tourists in Ljubljana, Portorož and Zreče in August 2007, by means of a personal interview. For each of the three destinations, the quota sample framework followed the representative tourist structure by the country of origin. Due to control over the respondent selection, we believe that relevant units were included.

\section{Dimensionality, Reliability and Validity of the Scales}

In order to assess the reliability and validity of the scales, exploratory (EFA) and confirmatory factor analyses (CFA) were conducted. First, we assessed the dimensionality of the single constructs (quality, perceived value, satisfaction and hotel image). EFA shows the multidimensionality of two scales, namely hotel quality and perceived value. Confirmatory factor analyses (CFA) were performed for both scales. Every time, two measurement models were compared: one-factor model, where constructs were conceptualized as one-dimensional and the covariance for all the items can be accounted for by a single factor and multi-factor model, where constructs were conceptualized as multi-dimensional and where covariation among the items can be accounted for by several, restricted first-order factors.

Summary statistics for models of hotel quality and perceived value constructs are shown in Table 1. Multi-factor models were, in both cases, found to outperform the one-factor 
DRUŠ. ISTRAŽ. ZAGREB GOD. 20 (2011) BR. $3(113)$

STR. 605-624

MILFELNER, B., SNOJ, B., PISNIK KORDA, A.: MEASUREMENT OF. model on absolute measures $\left(\chi^{2}, \mathrm{GFI}\right.$, and RMSEA), incremental fit measure (CFI), and parsimonious fit measures $\left(\chi^{2} / \mathrm{df}\right)$. Hotel quality construct is reflected in three sub-constructs: quality of personnel, quality of information, and core service quality. Perceived value is reflected in two sub-constructs, namely cognitive value and emotional value. Overall assessment of the guest satisfaction and hotel image model provide evidence that the constructs are one-dimensional, since all the fit indices are in the range of a good fit.

\begin{tabular}{|c|c|c|c|c|}
\hline & Perceived quality & Perceived value & Satisfaction & Image \\
\hline One-factor model & $\begin{array}{l}1 \text { factor } \\
\chi^{2} / \mathrm{df}=409.25 / 54 \\
\mathrm{p}<0.05 \\
\text { RMSEA }=0.127 \\
\mathrm{NFI}=0.628 \\
\mathrm{NNFI}=0.567 \\
\mathrm{CFI}=0.646 \\
\mathrm{RMR}=0.120 \\
\text { GFI }=0.749\end{array}$ & $\begin{array}{l}1 \text { factor } \\
\chi^{2} / \mathrm{df}=13.16 / 9 \\
\mathrm{p}=0.155 \\
\text { RMSEA }=0.033 \\
\mathrm{NFI}=0.942 \\
\mathrm{NNFI}=0.918 \\
\mathrm{CFI}=0.951 \\
\mathrm{RMR}=0.049 \\
\text { GFI }=0.959\end{array}$ & $\begin{array}{l}1 \text { factor } \\
\chi^{2 / d f}=2.81 / 2 \\
p=0.245 \\
\text { RMSEA }=0.032 \\
\text { NFI }=0.995 \\
\text { NNFI }=0.993 \\
\text { CFI }=0.998 \\
\text { RMR }=0.012 \\
\text { GFI }=0.995\end{array}$ & $\begin{array}{l}1 \text { factor } \\
\chi^{2} / \mathrm{df}=29.85 / 5 \\
\mathrm{p}<0.05 \\
\text { RMSEA }=0.110 \\
\mathrm{NFI}=0.938 \\
\mathrm{NNFI}=0.888 \\
\mathrm{CFI}=0.944 \\
\mathrm{RMR}=0.024 \\
\text { GFI }=0.955\end{array}$ \\
\hline Multi-factor model & $\begin{array}{l}3 \text { factors } \\
\chi^{2} / \mathrm{df}=49.54 / 32 \\
\mathrm{p}=0.0246 \\
\text { RMSEA }=0.037 \\
\text { NFI }=0.940 \\
\text { NNFI }=0.944 \\
\text { CFI }=0.960 \\
\text { RMR }=0.054 \\
\text { GFI }=0.957\end{array}$ & $\begin{array}{l}2 \text { factors } \\
\chi^{2} / \mathrm{df}=10.04 / 8 \\
\mathrm{p}=0.262 \\
\text { RMSEA }=0.025 \\
\mathrm{NFI}=0.957 \\
\mathrm{NNFI}=0.935 \\
\mathrm{CFI}=0.965 \\
\mathrm{RMR}=0.040 \\
\mathrm{GFI}=0.968\end{array}$ & & \\
\hline
\end{tabular}

is TABLE 1

Summary statistics for multi- and one-factor models
* quality of personnel, quality of information, core service quality, and supplement service quality

** cognitive value and emotional value

To obtain a more favorable number of parameters for estimation, we conducted an additional simplification of two, first order factors with more than two underlying factors. Specifically, for hotel quality and perceived value, second order factor models were computed. This was achieved by averaging the corresponding indicators leading to a single composite indicator. The final result of this stage is a perceived value factor with two indicators and a hotel quality factor with four indicators. Next, in order to show the degree to which a measure represents the construct it is supposed to represent, construct validity of single scales was assessed by examining convergent and discriminant validity. Evidence of convergent validity in the single constructs was determined separately for both groups (Slovenian and Italian tourists) by inspection of 
the variance extracted for each factor. Results are shown in Table 2. According to Fornell and Larcker (1981), convergent validity is established if the variance extracted value exceeds 0.50

(1) TABLE 2

Items, standardized loadings, CR and AVE for both groups Slovenian and Italian tourists) for a factor. CFA results for both groups show that in most of the cases (with the exception of hotel quality for the Italian group), average variance extracted reaches or exceeds the suggested value of 0.50 .

\begin{tabular}{|c|c|c|c|c|c|c|c|c|c|c|}
\hline \multirow[t]{2}{*}{ Construct/Items } & \multicolumn{5}{|c|}{ Slovenian tourists } & \multicolumn{5}{|c|}{ Italian tourists } \\
\hline & Mean & SD & $\lambda^{* *}$ & $\mathrm{CR}$ & AVE & Mean & SD & $\lambda^{* *}$ & $\mathrm{CR}$ & AVE \\
\hline \multicolumn{11}{|l|}{ Hotel quality* } \\
\hline Core service quality & 4.34 & 0.606 & 0.67 & 0.80 & 0.58 & 4.34 & 0.606 & 0.67 & 0.73 & 0.47 \\
\hline Quality of staff & 4.42 & 0.611 & 0.89 & & & 4.42 & 0.611 & 0.75 & & \\
\hline Quality of Information & 4.39 & 0.649 & 0.71 & & & 4.39 & 0.649 & 0.60 & & \\
\hline \multicolumn{11}{|l|}{ Perceived value* } \\
\hline Emotional value & 4.27 & 0.669 & 0.83 & 0.72 & 0.57 & 4.27 & 0.669 & 0.91 & 0.82 & 0.70 \\
\hline Rational value & 4.03 & 0.737 & 0.70 & & & 4.03 & 0.737 & 0.70 & & \\
\hline \multicolumn{11}{|l|}{ Guest satisfaction } \\
\hline \multicolumn{11}{|l|}{ General satisfaction with } \\
\hline your visit to this hotel & 4.39 & 0.701 & 0.84 & 0.87 & 0.62 & 4.39 & 0.701 & 0.84 & 0.84 & 0.57 \\
\hline $\begin{array}{l}\text { I am pleased that I decided } \\
\text { to visit this hotel. }\end{array}$ & 4.45 & 0.725 & 0.88 & & & 4.45 & 0.725 & 0.83 & & \\
\hline Visiting this hotel exceeded & & & & & & & & & & \\
\hline my expectations. & 3.60 & 1.131 & 0.62 & & & 3.60 & 1.131 & 0.68 & & \\
\hline I will speak highly & & & & & & & & & & \\
\hline of this hotel to my friends & & & & & & & 0811 & & & \\
\hline and colleagues. & 4.37 & 0.811 & 0.73 & & & 4.37 & 0.811 & 0.75 & & \\
\hline \multicolumn{11}{|l|}{ Hotel image } \\
\hline \multicolumn{11}{|l|}{ I think most people have } \\
\hline \multicolumn{11}{|l|}{ a positive opinion } \\
\hline about this hotel. & 4.42 & 0.653 & 0.71 & 0.80 & 0.50 & 4.42 & 0.653 & 0.71 & 0.84 & 0.51 \\
\hline \multicolumn{11}{|l|}{ The staff in this hotel is } \\
\hline friendly towards the guests. & 4.64 & 0.575 & 0.63 & & & 4.64 & 0.575 & 0.65 & & \\
\hline This hotel has a unique image. & 3.76 & 0.965 & 0.70 & & & 3.76 & 0.965 & 0.79 & & \\
\hline I think this hotel is popular. & 4.19 & 0.775 & 0.69 & & & 4.19 & 0.775 & 0.87 & & \\
\hline The staff in this hotel always & & & & & & & & & & \\
\hline put their guests first. & 4.47 & 0.697 & 0.69 & & & 4.47 & 0.697 & 0.68 & & \\
\hline
\end{tabular}

$\chi^{2 / \mathrm{df}}=383.11 / 149(\mathrm{p}>0.05) ; \mathrm{RMSEA}=0.088 ; \mathrm{NNFI}=0.910 ; \mathrm{CFI}=0.926 ; \mathrm{RMR}=0.053$

* composite indicators; ${ }^{* *}$ all $\lambda$ significant at $\mathrm{p}<0.01$

Additionally, all items of the single measures load significantly positive on their underlying factors (all loadings are higher than 0.50 and significant at $\mathrm{p}<0.05$ ) and that, indeed, is a test of convergent validity of the scale (See Table 3). Finally, discriminant validity was assessed for those scales with more than one construct (hotel quality and perceived value). 
DRUŠ. ISTRAŽ. ZAGREB GOD. 20 (2011),

BR. $3(113)$

STR. 605-624

MILFELNER, B., SNOJ, B. PISNIK KORDA, A.: MEASUREMENT OF..
Discriminant validity indicates the degree to which measures of conceptually distinct construct differ. Several CFAs were run for each possible pair of constructs and for both groups, first, allowing for correlation between the two various constructs, and then fixing the correlation between the constructs at one. In every case, the chi square differences between the fixed and free solutions were significant at $p<0.05$ or higher. Reliabilities of the constructs for hotel quality, perceived value, guest satisfaction and image were assessed with construct reliability measures. The reliability coefficients of the four subscales range from 0.72 to 0.87 for the Slovenian group and from 0.73 to 0.84 for the Italian group. This meets the standard of 0.60 , as suggested by Nunnally (1978). Thus, we assume that the scales used in this study reproduce consistent results in repeated measurements.

\section{Tests of Invariance between Both Groups}

Invariance measurement is implemented to ascertain whether the measurements are invariant across both groups of tourists. There is general agreement that the multi-group confirmatory factor analysis model represents the most powerful and versatile approach to testing cross-national measurement invariance (Steenkamp and Baumgartner, 1998). In order to compare the relationships concerning image value, hotel quality and hotel satisfaction in the structural model, one must first test for configural invariance, metric invariance and factor covariance invariance (Steenkamp and Baumgartner, 1998). Testing of error variance invariance is not obligatory, however, since our final structural model includes an error variance indicator, tests for error variance are also provided. Several competing models were constructed to test for four types of invariance. The results are presented in Table 3, while the loadings for all the indicators and both groups in the initial model are shown in Table 4.

Configural invariance was tested using the initial measurement model. For this purpose, we allowed all the loadings, covariance and error variances to be free across both groups. In the next step, metric invariance was assessed by constraining the matrix of factor loadings to be invariant between both groups. As can be observed in Table 3, the chi-square difference between the constrained and unconstrained models is insignificant, meaning the loadings of indicators are, in fact, invariant between both groups. The next step is testing for factor covariance invariance for both groups. The results show that the model is invariant for both groups, since no significant change in the chi-square statistics can be observed. Finally, tests for error variance invariance (added error variance constraints) were conducted. The hypothesis of full error variance invariance was rejected $\left(\Delta \chi^{2}(14)=85.65\right)$. After sequen- 
(1) TABLE 3

Results of invariance test for both groups (Slovenian and Italian tourists) tially relaxing the invariance constraints on five error variances, the resulting model shows an appropriate fit. Results reveal that the measurement model is mainly invariant between both groups, meaning that the understanding of the four concepts (hotel quality, perceived value, satisfaction, and hotel image) between Slovenian and Italian tourists is basically the same.

\begin{tabular}{lrrrrrrr}
\hline & $\chi^{2} \Delta$ & df & $\Delta \chi^{2}$ & $\Delta$ df & RMSEA & NNFI & CFI \\
\hline Configural invariance & 383.11 & 149 & & & 0.088 & 0.910 & 0.926 \\
Metric invariance & 398.26 & 159 & 15.15 & 10 & 0.086 & 0.915 & 0.925 \\
Covariance invariance & 400.06 & 162 & 1.80 & 3 & 0.085 & 0.915 & 0.925 \\
Full error variance invariance & 485.74 & 176 & 85.68 & 14 & 0.093 & 0.904 & 0.907 \\
Partial error variance invariance & 411.92 & 171 & 11.86 & 4 & 0.083 & 0.916 & 0.921 \\
& & & & & & &
\end{tabular}

\section{STRUCTURAL MODEL AND COMPARISON BETWEEN BOTH GROUPS OF TOURISTS}

In the final stage of the research, the proposed conceptual model was tested with structural equation modeling. In the first model, the matrix of regression coefficients was allowed to be different across both groups. The fit indices show appropriate fit $\left(\chi^{2}(165)=403.63 ; \mathrm{RMSEA}=0.084 ; \mathrm{NNFI}=0.915 ; \mathrm{CFI}=0.923\right)$. In the second model, regression coefficients were constrained between both groups. The model fit statistics are as follows: $\chi^{2}(170)=410.42 ; \mathrm{RMSEA}=0.084 ; \mathrm{NNFI}=0.916 ; \mathrm{CFI}=0.922$ ). Then, the test of chi-square difference was performed on the nested models to assess if the $\chi^{2}$ value was significantly lower for the unconstrained models (Anderson and Gerbing, 1982). The critical value $(p<0.05)$ was not exceeded, which means that the regression coefficients do not differ between both groups. The results indicate that the relationships between hotel image, perceived value, hotel quality and guest satisfaction does not differ between Slovenian and Italian tourists. The final model that is valid for both groups is presented in Figure 1.

P FIGURE 1

Standardized path estimates

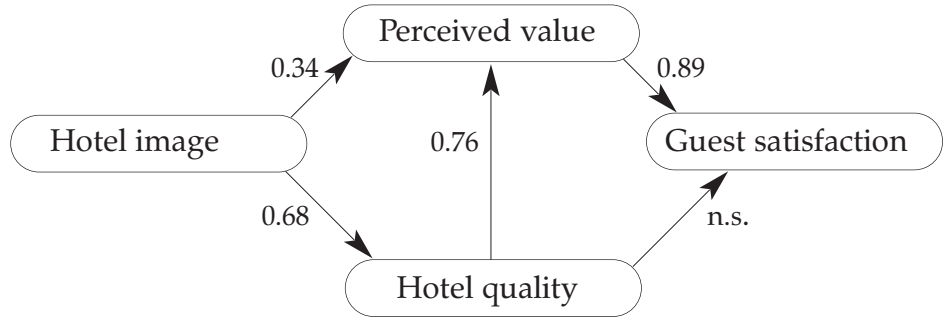

Fit indices: $\chi^{2}=403.63 \mathrm{df}=163 ; \mathrm{RMSEA}=0.084 ; \mathrm{NFI}=0.877 ; \mathrm{NNFI}=0.915$; $\mathrm{CFI}=0.923 ; \mathrm{RMR}=0.069 ; \mathrm{GFI}=0.940$ 


\begin{tabular}{lrrr}
\hline Relationships & $\begin{array}{c}\text { Standardized } \\
\text { regression coefficient }\end{array}$ & t-value & Significance \\
\hline H1: Hotel quality - perceived value & 0.763 & 5.207 & $\mathrm{p}<0.01$ \\
H2: Hotel quality - guest satisfaction & 0.205 & 1.597 & $\mathrm{n} . \mathrm{s}$ \\
H3: Hotel image - perceived value & 0.436 & 4.077 & $\mathrm{p}<0.01$ \\
H4: Hotel image - hotel quality & 0.636 & 10.096 & $\mathrm{p}<0.01$ \\
H5: Perceived value - guest satisfaction & 0.892 & 8.917 & $\mathrm{p}<0.01$ \\
\hline
\end{tabular}

(1) TABLE 4

Standardized estimated effects within the causal model
Table 4 provides an overview of estimated effects within the causal model with regard to the selected hypotheses. The relationship between hotel quality and perceived value is strong and positive $(\beta=0.763 ; p<0.01)$ and according to this finding, we can give support to $\mathrm{H} 1$. The relationship between hotel quality and guest satisfaction is much weaker and insignificant, which shows us that hotel quality does not directly influence guest satisfaction, and therefore, we reject $\mathrm{H} 2$. Therefore, it can be assumed that the relationship between hotel quality and guest satisfaction is not direct, but rather indirect through perceived value. As predicted by $\mathrm{H} 3$ and $\mathrm{H} 4$, hotel image is significantly positively related to both perceived value $(\beta=0.436 ; p<0.01)$ and hotel quality $(\beta=0.636$; $\mathrm{p}<0.01)$. Thus, both hypotheses are supported. Perceived value also strongly impacts hotel guest satisfaction $(\beta=0.892$; $\mathrm{p}<0.01)$. Consequently, H5 is also supported. The final hypothesis, H6, concerning the differences of relationships among perceived quality, image, perceived value and satisfaction between tourists from Slovenia and tourists from Italy, is not supported, since there are no significant differences between regression coefficients of both groups. Also, invariance analysis proves that understanding of the four concepts and their indicators (hotel quality, perceived value, satisfaction, and hotel image) between Slovenian and Italian tourists is congruent.

\section{CONCLUSIONS}

In current circumstances of increased global competition and economic recession, it is of prime importance that companies operating in the tourism industry seriously account for the universal law of "the survival of the fittest". Further, in the hotel industry, products and services are, in general, homogenous in nature, so it is important for hotel marketers to seek ways to differentiate their offerings from competitors. Consequently, one of the most important managerial tasks is to increase the perceived value of tourism offerings to customers by increasing the benefits of their offerings. The present research fills existing research gaps concerning the general lack of: using complex perceived value models; research deal- 
DRUŠ. ISTRAŽ. ZAGREB GOD. 20 (2011), BR. 3 (113)

STR. 605-624

MILFELNER, B., SNOJ, B., PISNIK KORDA, A.: ing with the perceived value as a crucial component of overall guest perceptions of services in tourism and also hotel services; research projects dealing with antecedents and consequences of hotel services perceived value; and research of differences between tourists coming from different cultural environments concerning the relationship between perceived value and its antecedents and consequences.

As suggested by several authors (e.g., Cronin et al., 2000; Cronin and Taylor, 1994; Parasuraman et al., 1985), our results indicate that service quality is a multidimensional construct. Further, our findings support the external validity of the three hotel service quality dimensions, namely: core service quality, quality of staff and quality of information. Perceived value of hotel services also proves to be a two-dimensional construct that comprises cognitive and emotional aspects of benefits and sacrifices, as suggested by other authors (e.g., Gallarza and Saura, 2006; Sanchez et al., 2006). In accordance with rare existing findings (e.g., Sanchez et al., 2006; Gallarza and Saura, 2006), our research indicates that apart from cognitive reasoning, feelings and emotions play a significant role in the purchasing behaviors of hotel guests and, therefore, should not be neglected in any research dealing with hotel guest perceptions. Considering the multidimensionality of perceived value, both relevant dimensions of the concept are included and confirmed to be reliable and valid.

Other contributions of the study are as follows. First, hotel guest perceived value has two important antecedents: perceived hotel quality and hotel image. Both constructs have a positive impact on perceived value. However, perceived quality is relatively more important in contributing to higher perceived value. Perceived quality is per se more related to perceived value, since it is an important aspect of benefits, as the core dimension of perceived value. While rare empirical researches in tourism (Kandampully and Hu, 2007; Kandampully and Suhartanto, 2000) show that relationships among image and customer satisfaction and loyalty are positive, no extant research in the tourism industry deals with a direct relationship between image and perceived value. Results of this study confirm the rationale that guest perceptions of hotel image influence guest perceptions of value, and indirectly, guest satisfaction with the hotel experience. In addition to its cognitive component, image includes an emotional component that, especially in the tourism industry, has an important impact on tourist value perceptions. Therefore, guest's perceived value of hotel services is the key mediating variable in relationships between hotel image and hotel guest satisfaction, and between perceived hotel quality and hotel guest satisfaction. 
DRUŠ. ISTRAŽ. ZAGREB GOD. 20 (2011),

BR. $3(113)$

STR. 605-624

MILFELNER, B., SNOJ, B. PISNIK KORDA, A.: MEASUREMENT OF.
Second, the results of this study clearly indicate that hotel image has a significant, direct and positive impact on perceived quality. As already explained, image consists of mainly emotional perceptions that are related to past experiences, and is an important antecedent of perceived quality, which also includes a set of subjective components.

Third, the direct relationship between hotel quality and satisfaction is much weaker than the indirect relationship through perceived value. Clearly, perceived hotel quality, by itself, does not necessarily directly produce greater levels of satisfaction, since it does not include the concept of sacrifice, which is a prominent dimension of hotel service value. According to the quality-value-satisfaction chain, our results indicate that hotel service quality is an antecedent of perceived value, with satisfaction as a behavioral consequence of perceived value. Consequently, we prove that models that consider only direct relationships between quality and satisfaction provide an incomplete picture of the drivers of customer satisfaction.

Fourth, the present study is, according to our knowledge, a pioneering one in the field of cross-national research, exploring differences among the relationships of hotel services perceived value, its antecedents and its consequences. The results indicate that the relationships among hotel image, perceived value, hotel quality and guest satisfaction do not differ for Slovenian and Italian tourists. An explanation of this finding may include multiple root causes, concerning their similar levels of expectation (e.g., cultural and historical factors, experiences with hotel services, etc.). Further contribution of the study concerns the general validity of the measurement instrument, which, according to performed invariance tests, proves to be appropriate in the case of collecting data from other hotel guest nationalities. Of course, use in comparative studies of hotel guests from different countries demands further invariance comparisons.

\section{Managerial Implications}

The study emphasizes that marketing practitioners and managers in the hotel industry should focus their efforts on the perceived value of their offerings, since value proves to be the crucial concept with decisive impact on hotel competitive advantage, and consequently, hotel performance. However, this may not be an easy task, since perceived value of hotel services is a multidimensional concept that comprises both cognitive and emotional elements. Thus, managers should also devote their attention to the cognitive (e.g., price discounts, 
DRUŠ. ISTRAŽ. ZAGREB GOD. 20 (2011), BR. 3 (113),

STR. 605-624

MILFELNER, B., SNOJ, B., PISNIK KORDA, A.: ledge, value for money) and the emotional dimensions (e.g., sense of joy, meeting interesting people) of hotel service benefits and sacrifices. Moreover, investments in hotel service perceived value are multiplied with greater care for perceived quality and hotel image.

Perceived quality of hotel services is an important multidimensional concept, which consists of guest experiences of core service quality (e.g., professional performance of services, clean and tidy rooms, clean and tidy hotel), quality of staff (e.g., friendliness, trustworthiness, willingness to help guests, empathy) and quality of information (e.g., clear, accurate, accessible, and reliable information). In their decision making, managers should focus on all three quality dimensions, but of course, taking into account that each can have different importance for hotel guests. Also according to numerous authors, the concept of image as a set of target group subjective perceptions regarding organizational performance also deserves full attention and care. Therefore, without proper assessment of hotel guest perceptions regarding the important elements of the hotel and its competitor activities and without systematic decision making on changes regarding better hotel positioning, hotel management might be confronted with a decline in the levels of perceived quality and value of its services, and consequently, with a decline in guest satisfaction levels, loyalty and even, poor financial results.

Hotel managers should also be aware that perceived value by hotel guests influences hotel guest satisfaction, which, in most cases, also leads to guest decisions about whether or not to return to a particular hotel. Since the relationship between perceived value and hotel guest satisfaction is the strongest in the model, we suggest that hotel managers consider intelligence about how to add value to their offerings since the immediate consequence of such efforts is greater hotel guest satisfaction. For marketing practitioners and managers in the hotel industry, our study emphasizes that if there is harmony among all four concepts (perceived quality, perceived value, satisfaction and hotel image), better competitive positioning can be achieved. With top management support for maintaining a customer-driven focus through perceived value and other researched constructs, higher hotel performance levels are a likely outcome. Despite the fact that we did not confirm the hypotheses on the differences between tourists from Slovenia and tourists from Italy regarding the relationships among the research concepts, managers should account for the fact that their hotel guests from different countries may have different experiences and different cultural, social and other backgrounds. 


\section{Limitations and Further Research}

We recommend researchers to improve customer value measurement tools for fine tuning. An expanded model with more indicators on both sides of perceived value could be developed in the future. Due to the regression design, the relationships found could be spurious when independent and dependent variables in the model are correlated with other variables that are not included in the model. Preferably, the choice of such variables (or even control variables such as gender, social group or education) should be based on previous research findings or at least on clear reasoning. Concerning that, indicators of the concept of sacrifices should be incorporated in the model (e.g., price, perceived risk) as perceived value antecedents.

Also, the model could be better explained with the inclusion of relationships between perceived value and tourist future intentions (e.g., WOM, loyalty). In addition, the proposed model could be modified to allow standardized measurement of tourists' perceived value as well as satisfaction at the level of different individual suppliers (e.g., restaurants and other tourist service providers), as well as on the level of destination (e.g., Žabkar et al., 2009). Furthermore, as a common methodological basis for measuring guests' value perceptions, satisfaction and loyalty at different interaction points would help identify important elements in the integrated destination's offering and provide valuable managerial information for tourism service providers. With testing model in a broader scope of different cultural environments, researchers may better contribute to further development of an enhanced perceived value and satisfaction model.

Anderson, J. C. \& Gerbing, D. W. (1982), Some Methods for Respecifying Measurement Models to Obtain Unidimensional Construct Measurement. Journal of Marketing Research, 19 (4): 453-460. doi:10.2307/ 3151719

Bolton, R. N. \& Drew, J. H. (1991), A Multistage Model of Customers' Assessments of Service Quality and Value. Journal of Consumer Research, 17 (4): 375-384. doi:10.1086/208564

Boo, S., Busser, J. \& Baloglu, S. (2009), A Model of Customer-Based Brand Equity and Its Application to Multiple Destinations. Tourism Management, 30 (2): 219-231. doi:10.1016/j.tourman.2008.06.003

Briggs, S., Sutherland, J. \& Drummond, S. (2007), Are Hotels Serving Quality? An Exploratory Study of Service Quality in the Scottish Hotel Sector. Tourism Management, 28 (4): 1006-1019. doi:10.1016/j.tourman. 2006.08.015

Busacca, B. \& Padula, G. (2005), Understanding the Relationship between Attribute Performance and Overall Satisfaction. Theory, Measurement and Implications. Marketing Intelligence E Planning, 23 (6): 543-561. 
DRUŠ. ISTRAŽ. ZAGREB GOD. 20 (2011), BR. 3 (113)

STR. 605-624

MILFELNER, B., SNOJ, B., PISNIK KORDA, A.: MEASUREMENT' OF.
Caruana, A., Money, A. H. \& Berthon, P. R. (2000), Service Quality and Satisfaction - The Moderating Role of Value. European Journal of Marketing, 34 (11-12): 1338-1352.

Crompton, J. L. \& Love, L. L. (1995), The Predictive Validity of Alternative Approaches to Evaluating Quality of a Festival. Journal of Travel Research, 34 (1): 11-24. doi:10.1177/004728759503400102

Cronin, J. J., Brady, M. K. \& Hult, G. T. (2000), Assessing the Effects of Quality, Value, and Customer Satisfaction on Consumer Behavioral Intentions in Service Environments. Journal of Retailing, 76 (2): 193-218. doi:10.1016/S0022-4359(00)00028-2

Cronin, J. J. \& Taylor, S. A. (1992), Measuring Service Quality: A Reexamination and Extension. Journal of Marketing, 56 (3): 55-68. doi:10. 2307/1252296

Cronin, J. J. \& Taylor, S. A. (1994), SERVPERF versus SERVQUAL: Reconciling Performance-Based and Perceptions-Minus-Expectations Measurement of Service Quality. Journal of Marketing, 58 (1): 125-131. doi:10.2307/1252256

Ekinci, Y. \& Riley, M. (2001), Validating Quality Dimensions. Annals of Tourism Research, 28 (1): 202-223. doi:10.1016/S0160-7383(00)00029-3

Fombrun, C. J. \& Rindova, V. P. (2001), Fanning the Flame: Corporate Reputations as Social Constructions of Performance. In: J. Porac \& M. Ventresca (Ed.), Constructing Markets and Industries. New York, Oxford University Press.

Fornell, C. \& Larcker, D. F. (1981), Evaluating Structural Equation Models with Unobservable Variables and Measurement Error. Journal of Marketing Research, 18 (1): 39-50. doi:10.2307/3151312

Gallarza, M. G. \& Saura, I. G. (2006), Value Dimensions, Perceived Value, Satisfaction and Loyalty: An Investigation of University Students' Travel Behaviour. Tourism Management, 27 (3): 437-452. doi:10. 1016/j.tourman.2004.12.002

Grönroos, C. (2007), Service Management and Marketing: Customer Management in Service Competition, 3rd Ed., Chichester, John Wiley \& Sons.

Herbig, P. \& Milewicz, J. (1995), The Relationship of Reputation and Credibility to Brand Success. The Journal of Consumer Marketing, 12 (4): 5-11.

Homburg, C., Koschate, N. \& Hoyer, W. D. (2006), The Role of Cognition and Affect in the Formation of Customer Satisfaction: A Dynamic Perspective. Journal of Marketing, 70 (3): 21-31. doi:10.1509/ jmkg.70.3.21

Kandampully, J. \& Hu, J. J. (2007), Do Hoteliers Need to Manage Image to Retain Loyal Customers. International Journal of Contemporary Hospitality Management, 19 (6): 435-443.

Kandampully, J. \& Suhartanto, D. (2000), Customer Loyalty in the Hotel Industry: The Role of Customer Satisfaction and Image. International Journal of Contemporary Hospitality Management, 12 (6): 346-351.

Lee, Y. \& Chen, T. (2006), A Kano Two-Dimensional Quality Model in Taiwan's Hot Spring Hotels Service Quality Evaluations. Journal of American Academy of Business, 8 (2): 301-306. 
DRUŠ. ISTRAŽ. ZAGREB GOD. 20 (2011), BR. $3(113)$

STR. 605-624

MILFELNER, B., SNOJ, B. PISNIK KORDA, A.: MEASUREMENT' OF..
Mazursky, D. \& Jacoby, J. (1986), Exploring the Development of Store Images. Journal of Retailing, 62 (2): 145-165.

McDougall, G. H. G. \& Levesque, T. (2000), Customer Satisfaction with Services: Putting Perceived Value into Equation. Journal of Services Marketing, 14 (5): 392-410.

Nguyen, N. \& Leblanc, G. (2001), Corporate Image and Corporate Reputation in Customers' Retention Decisions in Services. Journal of Retailing and Consumer Services, 8 (4): 227-236. doi:10.1016/S09696989(00)00029-1

Nguyen, N. (2006), The Perceived Image of Service Cooperatives: An Investigation in Canada and Mexico. Corporate Reputation Review, 9 (1): 62-78. doi:10.1057/palgrave.crr.1550010

Nunnally, J. C. (1978), Psychometric Theory, New York, NY, McGraw-Hill.

Oliver, R. L. (1993), A Conceptual Model of Service Quality and Service Satisfaction. In: T. A. Swartz, D. E. Bowen \& S. W. Brown (Eds.), Advances in Services Marketing and Management (pp. 65-86), Greenwich, JAI.

Oliver, R. L. (1997), Satisfaction: A Behavioural Perspective on the Consumer, New York, McGraw-Hill.

Parasuraman, A., Zeithaml, V. A. \& Berry, L. L. (1985), A Conceptual Model of Service Quality and Its Implications for Future Research. Journal of Marketing, 49 (4): 41-50. doi:10.2307/1251430

Patterson, P. \& Spreng, R. A. (1997), Modeling the Relationship between Perceived Value, Satisfaction and Repurchase Intentions in a Business-to-Business Services Context: An Empirical Examination. International Journal of Service Industry Management, 8 (5): 415-432.

Petrick, J. F. (2002), Development of a Multi-Dimensional Scale for Measuring the Perceived Value of a Service. Journal of Leisure Research, 34 (2): 119-134.

Petrick, J. F. (2004). The Roles of Quality, Value, and Satisfaction in Predicting Cruise Passengers' Behavioral Intentions. Journal of Travel Research, 42 (4): 397-407. doi:10.1177/0047287504263037

Sanchez, J., Callarisa, L., Rodriguez, M. R. \& Moliner, A. M. (2006), Perceived Value of the Purchase of a Tourism Product. Tourism Management, 27 (3): 394-409. doi:10.1016/j.tourman.2004.11.007

Sanchez-Fernandez, R. \& Iniesta-Bonillo, M. A. (2007), The Concept of Perceived Value: A Systematic Review of the Research. Marketing Theory, 7 (4): 427-451. doi:10.1177/1470593107083165

Steenkamp, J. B. \& Baumgartner, H. (1998), Assessing Measurement Invariance in Cross-National Consumer Research. Journal of Consumer Research, 25 (1): 78-90. doi:10.1086/209528

Sweeney, J. C., Soutar, G. N. \& Johnson, L. W. (1999), The Role of Perceived Risk in the Quality-Value Relationship: A Study in a Retail Environment. Journal of Retailing, 75 (1): 77-105. doi:10.1016/S00224359(99)80005-0

Teas, R. K. \& Agarwal, S. (2000), The Effect of Extrinsic Product Cues on Consumers' Perception of Quality, Sacrifice, and Value. Journal of the Academy of Marketing Science, 28 (2): 278-290. doi:10.1177/00920 70300282008 
DRUŠ. ISTRAŽ. ZAGREB GOD. 20 (2011), BR. 3 (113)

STR. 605-624

MILFELNER, B., SNOJ, B., PISNIK KORDA, A.: MEASUREMENT' OF.
Truong, T.-H. \& Foster, D. (2006), Using HOLSAT to Evaluate Tourist Satisfaction at Destinations: The Case of Australia Holidaymakers in Vietnam. Tourism Management, 27 (5): 842-855. doi:10.1016/j.tourman. 2005.05.008

Ulaga, W. \& Chacour, S. (2001), Measuring Customer-Perceived Value in Business Markets: A Prerequisite for Marketing Strategy Development and Implementation. Industrial Marketing Management, 30 (6): 525-540. doi:10.1016/S0019-8501(99)00122-4

Ulaga, W. (2001), Customer Value in Business Markets: An Agenda for Inquiry. Industrial Marketing Management, 30 (4): 315-319. doi:10. 1016/S0019-8501(01)00151-1

Woodall, T. (2003), Conceptualising Value for the Customer: A Structural, Attributional and Dispositional Perspective. Academy Of Marketing Science, 12. Available: http://www.amsreview.org/articles/ woodall12-2003.pdf

Woodruff, R. (1997), Customer Value: The Next Source for Competitive Advantage. Journal of the Academy of Marketing Science, 25 (2): 139-153. doi:10.1007/BF02894350

Woodruff, R. B. \& Gardial, S. F. (1996), Know Your Customer: New Approaches to Understanding Customer Value and Satisfaction, Cambridge, Blackwell Publishers.

Zeithaml, V. (1988), Consumer Perceptions of Price, Quality and Value: A Means-End Model and Synthesis of Evidence. Journal of Marketing, 52 (3): 2-22. doi:10.2307/1251446

Zeithaml, V. A. (1987), Defining and Relating Price, Perceived Quality and Perceived Value (Report No. 87-101), Cambridge, MA, Marketing Science Institute.

Žabkar, V., Makovec Brenčič, M. \& Dmitrović, T. (2010), Modelling Perceived Quality, Visitor Satisfaction and Behavioural Intentions at the Destination Level, Tourism Management, 31 (4): 537-546. doi:10.1016/ j.tourman.2009.06.005

\section{Mierenje međuodnosa percipirane kvalitete, percipirane vrijednosti, imidža i zadovoljstva hotelskim uslugama: usporedba gostiju iz Slovenije i Italije}

Borut MILFELNER, Boris SNOJ, Aleksandra PISNIK KORDA Ekonomsko-poslovni fakultet, Maribor

U ovom se radu prvo predstavlja konceptualni model percipirane vrijednosti kao posredničke varijable u percepcijama hotelskih usluga od turistâ, a potom ga se testira modeliranjem strukturnim jednadžbama. Studija otkriva: (a) da je odnos između percipirane kvalitete hotela i percipirane vrijednosti snažan i pozitivan, (b) da odnos između kvalitete hotela i zadovoljstva gosta nije izravan 
DRUŠ. ISTRAŽ. ZAGREB GOD. 20 (2011)

BR. $3(113)$

STR. 605-624

MILFELNER, B., SNOJ, B., PISNIK KORDA, A. MEASUREMENT OF.. nego neizravan (percipiranom vrijednošću), (c) da je imidž hotela značajno pozitivno povezan s percipiranom vrijednosti i percipiranom kvalitetom hotela te (d) da percipirana vrijednost snažno utječe na zadovoljstvo hotelskoga gosta. Nadalje, analiza invarijance pokazuje da nema značajnih razlika u odnosima između percipirane kvalitete, imidža, percipirane vrijednosti i zadovolistva između turistâ iz Slovenije i turistâ iz Italije.

Ključne riječi: percipirana vrijednost, percipirana kvaliteta, imidž, zadovoljstvo hotelskoga gosta, invarijanca

\section{Wechselbeziehungen zwischen perzipierter Qualität, perzipiertem Wert, Image und der Zufriedenheit mit dem Hotelservice: Ein Vergleich zwischen Hotelgästen aus Slowenien und Italien}

Borut MILFELNER, Boris SNOJ, Aleksandra PISNIK KORDA Fakultät für Ökonomie und Betriebswirtschaft, Maribor

Die Verfasser präsentieren in ihrer Arbeit zunächst das konzeptuelle Modell perzipierter Werte als eine vermittelnde Variable bei der Wahrnehmung von Hotelserviceleistungen auf Seiten ausländischer Touristen, um es sodann anhand von Strukturgleichungen zu modellieren und zu testen. Dabei zeigte sich Folgendes: a) Es herrscht ein starker und positiver Bezug zwischen der perzipierten Qualität eines Hotels und dem perzipiertem Wert; b) der Bezug zwischen der Qualität eines Hotels und der Zufriedenheit des Hotelgastes besteht nicht unmittelbar, sondern entsteht über den perzipierten Wert; c) das Image eines Hotels steht in einem wesentlich positiven Zusammenhang mit dem perzipierten Wert und der perzipierten Qualität eines Hotels; d) die Zufriedenheit des Hotelgastes wird stark durch den perzipierten Wert beeinflusst. Eine Invarianzanalyse zeigt des Weiteren, dass es im Hinblick auf die untersuchten Phänomene keine nennenswerten Unterschiede zwischen slowenischen und italienischen Touristen gibt.

Schlüsselbegriffe: Perzipierter Wert, perzipierte Qualität, Image, Zufriedenheit des Hotelgastes, Invarianz 